\title{
Influence of oligosaccharide extracts from pea and lupin seeds on caecal fermentation in rats*
}

\section{J. Juśkiewicz ${ }^{1}$, Z. Zduńczyk ${ }^{1}$, M. Wróblewska ${ }^{1}$ and K. Gulewicz ${ }^{2}$}

\author{
${ }^{1}$ Institute of Animal Reproduction and Food Research, Polish Academy of Sciences \\ Tuwima 10, 10-747 Olsztyn, Poland \\ ${ }^{2}$ Institute of Bioorganic Chemistry, Polish Academy of Sciences \\ Noskowskiego 12/14, 61-704 Poznań, Poland
}

(Received 21 October 2002; revised version 15 January 2003; accepted 4 April 2003)

\begin{abstract}
The influence of replacing cellulose in a casein diet with oligosaccharides from lupin and pea seeds (diets LOS and POS, respectively) on the metabolism of the caecum was investigated in an experiment on Wistar rats. The experimental diets contained 3.89 or $4.87 \% \alpha$-galactosides and 2.8 or $2.0 \%$ sucrose (LOS and POS, respectively). In rats receiving the diet with oligosaccharides, a greater weight of digesta and caecal tissue (especially in the LOS group), as well as a higher $\mathrm{pH}$ (range 7.15-7.37) and ammonia concentration $(46-51 \mathrm{mg} / 100 \mathrm{~g})$ in the caecal content were recorded, compared with the control group ( 7.03 and $24 \mathrm{mg} / 100 \mathrm{~g}$, respectively). In rats fed diets with oligosaccharide extracts, the dry matter of caecal digesta was significantly lower and activities of bacterial $\beta$ - and $\alpha$-galactosidase, $\alpha$-glucosidase and $\beta$-glucuronidase were significantly higher. The concentration of short-chain fatty acids in the caecum digesta was higher in rats given pea oligosaccharides $(129.16 \mu \mathrm{mol} / \mathrm{g}$ fresh digesta), than in rats fed with lupin-extract $(98.55 \mu \mathrm{mol} / \mathrm{g})$ and rats fed the diet with cellulose $(112.58 \mu \mathrm{mol} / \mathrm{g})$. Compared with cellulose, the total production of SCFAs in the caecum (expressed as $\mu \mathrm{mol} / 100 \mathrm{~g} \mathrm{BW}$ ) was significantly higher when the diet contained $4.87 \%$ $\alpha$-galactosides from pea (POS-group) and insignificantly higher when the diet contained $3.89 \%$ of lupin $\alpha$-galactosides (LOS-group).
\end{abstract}

KEY WORDS: $\alpha$-galactosides, caecum, glycolytic enzymes, short-chain fatty acids

\footnotetext{
* Supported by the State Committee for Scientific Research, Grant No. PBZ-KBN/020/P06/1999
} 


\section{INTRODUCTION}

Over the past decade, oligosaccharides have been an object of interest due to the possibility of their beneficial influence on the colon ecosystem (Cummings and Englyst, 1995). Diets containing oligosaccharides induce significant changes in the metabolism of the microbiota colonizing the gut and are able to stimulate the production of short-chain fatty acids (SCFA) (Ferguson and Jones, 2000). The most studied oligosaccharides are fructooligosaccharides which stimulate the growth of bifidobacteria in the caecum and colon (Cummings et al., 2001); information concerning the in vivo effects of oligosaccharides of grain legumes is insufficient. The oligosaccharides present in many legume seeds are $\alpha$-galactosyl derivatives, mono-, di- and tri- $\alpha$-galactosylsucrose, known respectively as raffinose, stachyose and verbascose. The results of earlier experiments show that $\alpha$-galactosides are, in part, responsible for a lower nutritional value of diets due to e.g. increasing the osmolarity of the small intestine (Wiggins, 1984) as well as increasing the viscosity of digesta (Smits and Annison, 1996). Although digestion of $\alpha$-galactosides in the small intestine may be relatively high due to microbial activity (Gdala et al., 1997; Smiricky et al., 2002), most of the digestion presumably occurs in the large intestine (Prince et al., 1988). The results of several experiments showed that $\alpha$-galactosides may be selective growth factors for beneficial bacteria in the large bowel (Hayakawa et al., 1990; Gulewicz et al., 2002).

A better understanding of how $\alpha$-galactosides affect gastrointestinal physiology will make it possible to utilize oligosaccharide extracts from legume seeds in human and animal diets. The purpose of that study was to evaluate the in vivo effects of $\alpha$-galactoside preparations obtained from lupin and pea seeds on caecal development and bacterial glycolytic activity in rats.

\section{MATERIAL AND METHODS}

\section{$\alpha$-Galactoside preparations}

$\alpha$-Galactosides were extracted from L. angustifolius L. cv. Mirela and Pisum sativum L. cv. Opal seeds as described by Gulewicz et al. (2000). After purification, the oligosaccharide preparations from pea and lupin contained 61.0 and $48.5 \%$ of total $\alpha$-galactosides, respectively. The lupin extract was free from alkaloids. The chemical composition and contents of particular sugars are presented in Table 1.

\section{Animals and diets}

The experiment lasted 2 weeks and was conducted on Wistar rats aged 40-45 days and weighing $107 \pm 3 \mathrm{~g}$. The control group was fed with a casein diet contai- 
TABLE 1

The content of oligosaccharides in legume extracts and experimental diets, \% air dry matter

\begin{tabular}{lcccccc}
\hline & \multicolumn{2}{c}{ Extract from seeds ${ }^{1}$} & & \multicolumn{3}{c}{ Diets } \\
\cline { 2 - 3 } \cline { 5 - 7 } \cline { 5 - 7 } & lupin & pea & & control $^{2}$ & LOS $^{3}$ & POS $^{4}$ \\
\hline Sucrose & 35.0 & 24.5 & & - & 2.80 & 1.96 \\
Raffinose & 3.1 & 12.3 & & - & 0.25 & 0.98 \\
Stachyose & 32.7 & 40.9 & & - & 2.62 & 3.27 \\
Verbascose & 12.7 & 7.8 & & - & 1.02 & 0.62 \\
Total $\alpha$-galactosides & 48.5 & 61.0 & & - & 3.89 & 4.87 \\
\hline
\end{tabular}

${ }^{1}$ the content of dry matter, crude protein, crude ash and other ingredients was as follows: in lupin preparation $-94,8.37,2.82$, and $0.13 \%$; in pea preparation - $95.60,7.54,2.46$, and $0.09 \%$, respectively

${ }^{2}$ composition of control diet, \%: casein - 14.8, DL-methionine - 0.2 , soya oil - 10, cellulose - 5, maize starch - 62, mineral mixture (AIN-93G) - 3, vitamin mixture (AIN-93G) - 2

${ }^{3}$ diet with lupin oligosaccharide

${ }^{4}$ diet with pea oligosaccharide

ning 5\% cellulose, and experimental groups were fed with a diet in which cellulose was replaced with lupin or pea oligosaccharides (L-OS and P-OS, respectively). The composition of extracts and content of $\alpha$-galactosides in diets are presented in Table 1. The diets contained about $13.5 \%$ crude protein (control 13.1\%, POS $13.9 \%$ and LOS $13.8 \%$ ), a standard amount of mineral mixture (according to AIN-93G Mineral Mix) and vitamin mixtures (according to AIN-93G Vitamin Mix), soya oil $10 \%$ and maize starch $62 \%$.

Experimental groups consisted of eight male rats housed individually in metabolic cages in a room with a 12-h light-dark cycle, a temperature of $21 \pm 1^{\circ} \mathrm{C}$, relative humidity of $50 \pm 5 \%$ and 20 air changes/h. Animals had free access to water and diets.

\section{Caecal parameters}

At the termination of the experiment, the rats were anaesthetized using sodium pentobarbitone according to the recommendation for euthanasia of experimental animals (Close et al., 1997). After laparotomy, the caecum with contents was removed and weighed. The caecal $\mathrm{pH}$ was measured using a microelectrode and $\mathrm{pH} / \mathrm{ION}$ meter (model 301, Hanna Instruments). Samples of fresh digesta were used for immediate analysis (dry matter content, ammonia and SCFAs concentrations), the rest was transferred to microfuge tubes and stored at $-40^{\circ} \mathrm{C}$. The caecum wall was flushed clean with ice-cold saline, blotted on filter paper and weighed as the caecum wall mass. Dry matter of the caecal content was determined at $105^{\circ} \mathrm{C}$. Ammonia was determined in fresh caecal digesta according to the standard Conway's method. 
Caecal content was analysed for SCFA concentration by gas chromatography (Shimadzu GC-14A with a glass column $2.5 \mathrm{~m} \times 2.6 \mathrm{~mm}$, containing 10\% SP$1200 / 1 \% \mathrm{H}_{3} \mathrm{PO}_{4}$ on $80 / 100$ Chromosorb W AW, column temperature $110^{\circ} \mathrm{C}$, detector FID temperature $180^{\circ} \mathrm{C}$, injector temperature $195^{\circ} \mathrm{C}$ ). The caecal digesta were weighed (sample of about $0.2 \mathrm{~g}$ ), mixed with $0.2 \mathrm{~mL}$ formic acid, diluted with deionized water and centrifuged at $10000 \mathrm{x}$ g for $5 \mathrm{~min}$. The supernatant was decanted for injection into a gas chromatograph. Caecal SCFA pool size was calculated as the product of SCFA concentration in digesta and caecal digesta mass.

Glycolytic activity in the caecal digesta was measured by the rate of release of p- or o-nitrophenol from their nitrophenylglucosides according to the modified method of Djouzi and Andrieux described by Juśkiewicz et al. (2002). The following substrates were used: for $\beta$-glucuronidase: $p$-nitrophenyl- $\beta$-D-glucuronide, for $\alpha$-galactosidase: $p$-nitrophenyl- $\alpha$-D-galactopyranoside, for $\beta$-galactosidase: o-nitrophenyl- $\beta$-D-galactopyranoside, for $\alpha$-glucosidase: $p$-nitrophenyl- $\alpha$-D-glucopyranoside, and for $\beta$-glucosidase: $\mathrm{p}$-nitrophenyl- $\beta$-D-glucopyranoside. The reaction mixture contained $0.3 \mathrm{~mL}$ substrate solution $(5 \mathrm{mM})$ and $0.2 \mathrm{~mL}$ of a $1: 10(\mathrm{v} / \mathrm{v})$ dilution of the caecal sample in $100 \mathrm{mM}$ phosphate buffer ( $\mathrm{pH} 7.0$ ) after centrifugation at $10000 \mathrm{xg}$ for $15 \mathrm{~min}$. Incubation was carried out at $37^{\circ} \mathrm{C}$ and $\mathrm{p}$-nitrophenol was quantified at $400 \mathrm{~nm}$ and at $420 \mathrm{~nm}$ (o-nitrophenol concentration) after addition of $2.5 \mathrm{~mL} 0.25 \mathrm{M}$ cold sodium carbonate. Enzymatic activity ( $\alpha$ - and $\beta$-glucosidase, $\alpha$ - and $\beta$-galactosidase, and $\beta$-glucuronidase) was expressed as $\mu \mathrm{mol}$ product formed per min (IU) per g protein (or digesta) in the caecal sample. The protein content in the supernatant was determined by the Lowry's method (1951) using BSA as the standard.

\section{Statistical analysis}

The results were analysed using one-way ANOVA and significant differences between groups were determined by Duncan's multiple range test. Differences were considered significant at $\mathrm{P} \leq 0.05$ and $\mathrm{P} \leq 0.01$.

\section{RESULTS}

The body weights of rats fed for 14 days diets with or without the oligosaccharide preparations were similar (Table 2). Diet intake during the whole experimental period was unaffected by the addition of 3.89 (LOS-group) and $4.87 \%$ (POS-group) of $\alpha$-galactosides to the diet. Supplementation of diets with oligosaccharides induced enlargement of the caecum (wall mass and digesta), especially in the LOS-group. Oligosaccharides decreased the dry matter concentration in the caecum, more in the POS than in the LOS group, but the dry matter content in 
TABLE 2

Body weight gain and caecal parameters in rats fed with experimental diets

\begin{tabular}{lcccc}
\hline Indices & Control $^{1}$ & LOS $^{2}$ & POS $^{3}$ & SEM \\
\hline Initial body weight, g & 123.5 & 123.5 & 123.4 & 0.71 \\
Final body weight, g & 178.0 & 184.3 & 184.3 & 1.56 \\
Body weight gain, g/14 days & 54.6 & 60.8 & 60.9 & 1.51 \\
Diet intake, g/14 days & 245.1 & 249.6 & 246.8 & 2.46 \\
Whole caecum, g/100 g BW & $1.44^{\mathrm{Bb}}$ & $1.79^{\mathrm{Aa}}$ & $1.58^{\mathrm{ABb}}$ & 0.05 \\
Caecal tissue, g/100 g BW & $0.33^{\mathrm{Bc}}$ & $0.41^{\mathrm{Aa}}$ & $0.38^{\mathrm{Ab}}$ & 0.009 \\
Caecal digesta, g/100 g BW & $1.11^{\mathrm{Bb}}$ & $1.38^{\mathrm{Aa}}$ & $1.20^{\mathrm{ABb}}$ & 0.041 \\
Caecal dry matter, g/100 g BW & 0.25 & 0.26 & 0.21 & 0.02 \\
DM of caecal digesta, $\%$ & $22.6^{\mathrm{A}}$ & $19.5^{\mathrm{B}}$ & $17.8^{\mathrm{C}}$ & 0.491 \\
pH of caecal digesta & $7.03^{\mathrm{Bb}}$ & $7.15^{\mathrm{ABb}}$ & $7.37^{\mathrm{Aa}}$ & 0.053 \\
Ammonia concentration in caecal & $0.24^{\mathrm{B}}$ & $0.51^{\mathrm{A}}$ & $0.46^{\mathrm{A}}$ & 0.003 \\
$\quad$ digesta, mg/g & $0.13^{\mathrm{C}}$ & $0.24^{\mathrm{A}}$ & $0.19^{\mathrm{B}}$ & 0.011 \\
\hline Lowry's protein in caecal digesta, $\mathrm{mg} / \mathrm{g}$ & & & & \\
\hline
\end{tabular}

$1,2,3$ explanation see Table 1

a,b values within each row with the same superscript are not different at $\mathrm{P} \leq 0.05$

$A, B, C$ values within each row with the same superscript are not different at $P \leq 0.01$

TABLE 3

Glycolytic activity in the caecal digesta of rats fed with experimental diets

\begin{tabular}{|c|c|c|c|c|}
\hline Microbial enzyme & Control $^{1}$ & $\mathrm{LOS}^{2}$ & $\mathrm{POS}^{3}$ & SEM \\
\hline \multicolumn{5}{|c|}{$\mathrm{U} / \mathrm{g}$ fresh caecal content } \\
\hline$\beta$-glucuronidase & $0.49^{\mathrm{Bb}}$ & $1.89^{\mathrm{Aa}}$ & $0.93^{\mathrm{ABb}}$ & 0.210 \\
\hline$\beta$-glucosidase & 0.25 & 0.28 & 0.32 & 0.026 \\
\hline$\beta$-galactosidase & $1.68^{\mathrm{Bb}}$ & $14.14^{\mathrm{Aa}}$ & $8.92^{\mathrm{ABa}}$ & 1.680 \\
\hline$\alpha$-galactosidase & $0.60^{\mathrm{Bb}}$ & $6.86^{\mathrm{Aa}}$ & $3.83^{\mathrm{ABa}}$ & 0.823 \\
\hline$\alpha$-glucosidase & $1.06^{\mathrm{B}}$ & $3.21^{\mathrm{A}}$ & $2.90^{\mathrm{A}}$ & 0.282 \\
\hline \multicolumn{5}{|c|}{$\mathrm{U} / \mathrm{g} \operatorname{protein}^{4}$} \\
\hline$\beta$-glucuronidase & $76^{\mathrm{b}}$ & $152^{\mathrm{a}}$ & $96^{\mathrm{ab}}$ & 15.3 \\
\hline$\beta$-glucosidase & $38^{\mathrm{a}}$ & $22^{b}$ & $32^{\mathrm{ab}}$ & 2.8 \\
\hline$\beta$-galactosidase & $260^{\mathrm{Bb}}$ & $1142^{\text {Аa }}$ & $872^{\mathrm{ABa}}$ & 131.1 \\
\hline$\alpha$-galactosidase & $93^{\mathrm{Bb}}$ & $553^{\mathrm{Aa}}$ & $370^{\mathrm{ABa}}$ & 65 \\
\hline$\alpha$-glucosidase & $164^{\mathrm{Bb}}$ & $261^{\mathrm{ABa}}$ & $295^{\text {Аа }}$ & 19.3 \\
\hline
\end{tabular}

1,2,3 explanation see Table 1

4 according to the Lowry's method

${ }_{a, b}$ values within each row with the same superscript are not different at $\mathrm{P} \leq 0.05$

$A, B, C$ values within each row with the same superscript are not different at $P \leq 0.01$

the caecum (expressed as $\mathrm{g} / 100 \mathrm{~g} \mathrm{BW}$ ) of rats was similar in all groups. The caecal $\mathrm{pH}$ was about 7.0 in the control diet with cellulose and was increased to 7.37 in rats fed with the pea-preparation $(\mathrm{P} \leq 0.05)$, whereas it was intermediate in the LOS-group. Supplementation of the control diet with oligosaccharides caused a higher concentration of ammonia and protein in the caecal digesta.

Glycolytic activity in the caecal digesta, expressed both as IU per g protein or digesta was generally enhanced in rats fed oligosaccharides from both legumes (Table 3), but the effect of lupin oligosaccharides tended to be greater than that of the 
TABLE 4

The concentration $\left(\mu \mathrm{mol} / \mathrm{g}\right.$ fresh digesta) and total pool ${ }^{1}$ of SCFA $(\mu \mathrm{mol} / 100 \mathrm{~g} \mathrm{BW})$ in the caecum

\begin{tabular}{|c|c|c|c|c|}
\hline Concentration & Control $^{1}$ & $\mathrm{LOS}^{2}$ & $\mathrm{POS}^{3}$ & SEM \\
\hline Total SCFA & $112.58^{\mathrm{AB}}$ & $98.55^{\mathrm{B}}$ & $129.16^{\mathrm{A}}$ & 4.16 \\
\hline Acetate & $66.26^{\mathrm{Ab}}$ & $54.01^{\mathrm{Bc}}$ & $76.12^{\mathrm{Aa}}$ & 4.39 \\
\hline Propionate & $21.99^{\mathrm{b}}$ & $21.91^{\mathrm{b}}$ & $28.83^{\mathrm{a}}$ & 1.21 \\
\hline Isobutyrate & $2.61^{\mathrm{Bb}}$ & $3.38^{\mathrm{Aa}}$ & $3.23^{\mathrm{ABa}}$ & 0.12 \\
\hline Butyrate & 15.34 & 13.58 & 12.62 & 0.86 \\
\hline Isovalerate & $2.69^{b}$ & $2.66^{\mathrm{b}}$ & $4.02^{\mathrm{a}}$ & 0.23 \\
\hline \multirow{3}{*}{$\begin{array}{l}\text { Valerate } \\
\mathrm{C}_{2}: \mathrm{C}_{3}: \mathrm{C}_{4} \text { profile, } \\
\mu \mathrm{mol} / 100 \mu \mathrm{mol} \text { total SCFA } \\
\text { Total pool }{ }^{1}\end{array}$} & $3.69^{\mathrm{AB}}$ & $3.01^{\mathrm{B}}$ & $4.34^{\mathrm{A}}$ & 0.17 \\
\hline & $59: 20: 14$ & $55: 22: 14$ & $59: 22: 10$ & - \\
\hline & $96.82^{\mathrm{B}}$ & $109.4^{\mathrm{AB}}$ & $127.9^{\mathrm{A}}$ & 4.02 \\
\hline \multicolumn{5}{|l|}{ 1,2,3 explanation see Table 1} \\
\hline $\begin{array}{l}{ }^{4} \text { caecal SCFA pool was calc } \\
\text { a,b values within each row wit }\end{array}$ & $\begin{array}{l}\mathrm{d} \text { as } \mathrm{SCF} \\
\text { same sup }\end{array}$ & $\begin{array}{l}\text { entration } x \\
\text { t are not } c\end{array}$ & $\begin{array}{l}1 \text { digesta/ } 10 \\
\text { at at } \mathrm{P} \leq 0.05\end{array}$ & \\
\hline
\end{tabular}

pea preparation. That effect was found in $\beta$ - and $\alpha$-galactosidase, and $\alpha$-glucosidase activities. The $\beta$-glucosidase activity, expressed as IU per g protein, in the control group was significantly higher than in the LOS-group, while in the POS-group it was intermediate. The $\beta$-glucuronidase activity in the caecal digesta was the lowest in the control group and the highest in the LOS-group.

Caecal concentrations of short-chain fatty acids (SCFAs) significantly differed between groups fed with oligosaccharide preparations, more SCFAs were produced in the caecum in the POS than in the LOS-group, while in rats fed with cellulose, SCFA production was intermediate (Table 4). With all substrates it was found that acetic, propionic and butyric acids together accounted for more than $90 \%$ of SCFAs in the digesta, with iso-butyric, isovaleric and valeric acids being present in relatively small amounts. When the $\mathrm{C}_{2}: \mathrm{C}_{3}: \mathrm{C}_{4}$ profile (expressed relative to the total amounts of the three SCFAs) is considered, pea-preparation fermentation produced a higher proportion of acetate than the LOS diet and lower proportion of butyrate compared with the control and LOS groups. The caecal SCFA pool, expressed as $\mu \mathrm{mol} / 100 \mathrm{~g} \mathrm{BW}$, was greater with oligosaccharide treatment than with cellulose due to the lower caecal content mass in the control group.

\section{DISCUSSION}

The results of the study (Table 2) indicate that oligosaccharides from lupin and pea at a level of 3.89 and $4.87 \%$, respectively, had no effect on the diet intake and body weight gain of rats. Similar results were obtained in our earlier studies with 
a lower level (2.92\%) of white lupin oligosaccharides (Zduńczyk et al., 1998). Application of oligosaccharide preparations in diets affected such caecal parameters as dry matter content, $\mathrm{pH}$, ammonia and protein concentration in the caecal digesta. The decreased dry matter content in the caecal digesta should be ascribed to the osmotic activity of oligosaccharides (Wiggins, 1984) and lower water absorption in the small intestine (Zduńczyk et al., 1998). The increase of pH and ammonia concentration can be explained by two factors: oligosaccharide preparations were also an additional source of protein in the diets; since oligosaccharides inhibit protein digestibility in the upper part of the gastrointestinal tract (Gdala et al., 1997), a part of dietary protein could escape digestion in the small intestine and was digested by bacteria in the caecum, thus increasing the $\mathrm{pH}$ of digesta and the ammonia concentration.

The oligosaccharide preparations used in our study affected the general glycolytic activities of the caecum ecosystem. $\beta$-glucosidase activity remained unaffected by the oligosaccharide treatment. $\beta$-galactosidase, $\alpha$-galactosidase, $\alpha$-glucosidase, as well as $\beta$-glucuronidase activities were enhanced in the LOS and POS groups. The obtained results confirm the report of Monsan and Paul (1995) that oligosaccharides stimulate enzyme production by intestinal bacterial flora, particularly of glycolytic enzymes, thus resulting in increased hydrolysis of insoluble carbohydrate polymers.

Intestinal bacterial $\beta$-glucuronidase deconjugates many compounds that are secreted into the intestine as glucuronide conjugates. These compounds may then be further modified by the bacteria in the large intestine to reactive metabolites (Buddington et al., 1996). Some results also showed that caecal $\beta$-glucuronidase activity remained unaffected (Kleessen et al., 1996) or was slightly higher (Bielecka et al., 2002) after consumption of a diet containing non-digestible oligosaccharides.

According to Macfarlane and Cummings (1991), the activity of $\beta$-galactosidase and $\alpha$-glucosidase can be enhanced when the diet contains higher amounts of easily-fermentable saccharides. In these circumstances, it can be assumed that the oligosaccharides provided by the preparation from lupin seeds were more easily fermented than those from pea seeds.

In our experiment, the lowest concentration of SCFA in the caecal digesta was found in the LOS group. It could be caused by a lower total content and different composition of $\alpha$-galactosides in the LOS than in the POS diet. Compared to the POS-group, the oligosaccharide extract used in the LOS diet contained less $\alpha$-galactosides and more sucrose, which was digested and absorbed in the small intestine. The results obtained for the POS group indicate that the diet containing the oligosaccharide extract with a higher content of $\alpha$-galactosides and lower content of sucrose caused higher production of SCFAs. The amount of oligosaccharides that reach the caecum can be affected by different breakdown rates of lupin- or pea-originated oligosaccharides in the small intestine (Gdala et al., 1997). Supple- 
mentation of the diet with the pea extract (containing more $\alpha$-galactosides) had no effect on the proportion of acetate in the SCFA pool. It is known that acetate is the main product of the metabolism of bifidobacteria, although Djouzi and Andrieux (1997) observed that glycolytic activities could be modified in a beneficial way without any change in the Bifidobacterium level.

In the present study, supplementation of diets with oligosaccharide preparations increased the production of short-chain fatty acids (SCFA) expressed as total pool of SCFA in the caecum of rats (Table 4). This was in accordance with the higher activity of glycolytic enzymes in the caecal content. The results obtained in vitro in the studies of Ferguson and Jones (2000) showed that fermentation of cellulose produced 3-fold less total SCFAs than raffinose-family oligosaccharides. In our experiment, significantly higher production of SCFAs was observed when dietary cellulose was substituted with the oligosaccharide preparation from pea seeds and the diet contained $4.87 \% \alpha$-galactosides (POS-group). A lower dietary concentration of $\alpha$-galactosides $(3.89 \%)$ in the LOS-group caused only an insignificant increase in the SCFA production in the caecum of rats compared with the diet containing cellulose.

\section{CONCLUSIONS}

Compared with cellulose, oligosaccharide preparations from lupin and pea influenced the caecal ecosystem. The preparations increased the amount of water, enhanced bacterial glycolytic activity, production of SCFA, and ammonia concentration but did not lower the $\mathrm{pH}$ of the caecal digesta. The oligosaccharide extract from pea containing more $\alpha$-galactosides and less sucrose caused higher production of SCFAs, while the extract from lupin seeds (containing less $\alpha$-galactosides and more sucrose), strongly increased the glycolytic activity in the caecal digesta without beneficial changes in the caecum of rats. In conclusion, supplementation of diets with lupin and pea oligosaccharides extracts caused significant changes in the functioning of the caecal ecosystem, however without decreasing $\mathrm{pH}$, ammonia content and activity of potentially harmful bacterial enzymes ( $\beta$-glucuronidase and $\beta$-glucosidase).

\section{REFERENCES}

Bielecka M., Biedrzycka E., Majkowska A., Juśkiewicz J., Wróblewska M., 2002. Effect of non-digestible oligosaccharides on gut microecosystem in rats. Food Res. Int. 35, 139-144

Buddington R.K., Williams C.H., Chen S-C., Witherly S.A., 1996. Dietary supplement of neosugar alters the faecal flora and decreases activities of some reductive enzymes in human subjects. Amer. J. Clin. Nutr. 63, 709-716 
Close B., Banister K., Baumans V., Bernoth E-M., Bromage N., Bunyan J., Erhardt W., Flecknell P., Gregory N., Hackbarth H., Morton D., Warwick C., 1997. Recommendations for euthanasia of experimental animals: Part 2. Lab. Animals 31, 1-32

Cummings J.H., Englyst H.N., 1995. Gastrointestinal effects of food carbohydrate. Amer. J. Clin. Nutr. 61, 938S-945S

Cummings J.H., Macfarlane G.T., Englyst H.N., 2001. Prebiotic digestion and fermentation. Amer. J. Clin. Nutr. 73, 415S-420S

Djouzi Z., Andrieux C., 1997. Compared effects of three oligosaccharides on metabolism of intestinal microflora in rats inoculated with a human faecal flora. Brit. J. Nutr. 78, 313-324

Ferguson M.J., Jones G.P., 2000. Production of short-chain fatty acids following in vitro fermentation of saccharides, saccharide esters, fructo-oligosaccharides, starches, modified starches and non-starch polysaccharides. J. Sci. Food Agr. 80, 166-170

Gdala J., Jansman A.J.M., Buraczewska L., Huisman J., van Leeuwen P., 1997. The influence of $\alpha$-galactosidase supplementation on the ileal digestibility of lupin seed carbohydrates and dietary protein in young pigs. Anim. Feed Sci. Tech. 67, 115-125

Gulewicz P., Cisiołka D., Frias J., Vidal-Valverde C., Frejnagel S., Trojanowska K., Gulewicz K., 2000. Simple method of isolation and purification of $\alpha$-galactosides from legumes. J. Agr. Food Chem. 48, 3120-3123

Gulewicz P., Szymaniec S., Bubak B., Frias J., Vidal-Valverde C., Trojanowska K., Gulewicz K., 2002. Biological activity of $\alpha$-galactoside preparations from Lupinus angustifolius L. and Pisum sativum L. seeds. J. Agr. Food. Chem., 50, 384-389

Hayakawa K., Mitzutani J., Wada K., Masai T., Yoshihara I., Mitsuoka T., 1990. Effect of soybean oligosaccharides on human fecal flora. Microbiol. Ecol. Health Dis. 3, 293-303

Juśkiewicz J., Zduńczyk Z., Wróblewska M., Oszmiański J., Hernandez T., 2002. The response of rats to feeding with diets containing grapefruit flavonoid extract. Food Res. Int. 35, 201-205

Kleessen B., Sykura B., Zunft H.J., Blaut M., 1996. Effects of inulin and lactose on faecal microflora, microbial activity, and bowel habit in elderly constipated persons. Amer. J. Clin. Nutr. 65, 1397-1402

Lowry O.H., Rosebrough N.J., Farr A.L., Randall R.J., 1951. Protein measurement with the Folin phenol reagent. J. Biol. Chem. 193, 265-275

Macfarlane G.T., Cummings J.H., 1991. The colonic flora, fermentation and large bowel digestive function. In: S.F. Phillips, J.H. Pemberton, R.G. Shorter (Editors). The Large Intestine: Physiology, Pathophysiology and Disease. Raven Press, New York, pp. 51-92

Monsan P.F., Paul F., 1995. Oligosaccharide feed additivies. In: R.J. Wallace, A. Chesson (Editors). Biotechnology in Animal Feeds and Feeding. Weinheim and New York, VCH Verlagsgesellschaft mBH, pp. 233-245

Smiricky M.R., Grieshop C.M., Albin D.M., Wubben J.E., Gabert V.M., Fahey G.C., 2002. The influence of soy oligosaccharides on apparent and true ileal amino acid digestibility and fecal consistency in growing pigs. J. Anim. Sci. 80, 2433-2441

Smits C.H.M., Annison G., 1996. Non-starch plant polysaccharides in broiler nutrition towards a physiologically valid approach to their determination. World Poultry Sci. J. 52, 204-221

Viggins H.S., 1984. Nutritional value of sugars and related compounds undigested in the small gut. Proc. Nutr. Soc. 43, 69-75

Zduńczyk Z., Juśkiewicz J., Frejnagel S., Gulewicz K., 1998. Influence of alkaloids and oligosaccharides from white lupin seeds on utilization of diets by rats and absorption of nutrients in the small intestine. Anim. Feed Sci. Tech. 72, 143-154 


\section{STRESZCZENIE}

\section{Wpływ ekstraktu oligosacharydów z nasion łubinu i grochu na fermentację w jelicie ślepym szczurów}

W doświadczeniu na szczurach Wistar badano wpływ uzupełnienia diet kazeinowych preparatami oligosacharydów z nasion łubinu (LOS) i grochu (POS) na przemiany w jelicie ślepym. Diety doświadczalna zawierały 3,89 lub 4,87\% $\alpha$-galaktozydów oraz 2,80 lub 1,96\% sacharozy (odpowiednio dieta LOS i POS). Dieta kontrolna była uzupełniona 5\% dodatkiem celulozy. W treści jelita ślepego szczurów otrzymujących dietę z dodatkiem oligosacharydów masa ściany jelita ślepego i jego zawartość były większe (zwłaszcza w grupie LOS), pH (7,15-7,37) wyższe, a stężenie amoniaku większe (46-51 mg/100 g) w treści jelita, w porównaniu z grupą kontrolną ( $\mathrm{pH} 7,03$; stężenie amoniaku $24 \mathrm{mg} / 100 \mathrm{~g}$ ). W jelicie ślepym szczurów żywionych dietami z ekstraktami oligosacharydów treść była bardziej uwodniona. W grupach doświadczalnych stwierdzono większą aktywność enzymów bakteryjnych $\beta$ - i $\alpha$-galaktozydazy, $\alpha$-glukozydazy i $\beta$-glukuronidazy. Większa zawartość oligosacharydów w preparacie grochu (61\%) powodowała zwiększoną produkcję krótkołańcuchowych kwasów tłuszczowych w treści jelita w porównaniu ze szczurami żywionymi dietą z ekstraktem z łubinu (zawierającym 48,5\% $\alpha$-galaktozydów). 